\title{
A study on sanitation, hygiene practices and food safety knowledge among food vendors in different sectors of Chandigarh, India
}

\author{
Uttara Singh \\ Foods and Nutrition, Govt. Home Science College Sector 10-D, Chandigarh-160036 \\ INDIA \\ Aradhana Thakur* \\ Foods and Nutrition, Govt. Home Science College Sector 10-D, Chandigarh-160036 \\ INDIA \\ *Corresponding author. E-mail:aradhanathakur222@gmail.com

\begin{abstract}
:
The present study were carried out to assess the hygiene practices and food safety among street food vendors in the city of Chandigarh. It includes 100 samples of vendors. Fifty vendors were mobile and other 50 was fixed vendors. A self planned questionnaire was used for data collection for the vendors. The questionnaire included questions about demographic information, hygiene practices and food safety. Thirty eight percent of vendors used stalls, but did not uphold their stalls well. Eighty-three per cent of the vendors had thrown garbage in the open vessel and $14.0 \%$ used dustbin for dispose garbage. Personal hygiene was also observed which indicated that the vendors never wear the head covers, handled food with bare hand and they did not wear overcoats/aprons as well. Street food vendors were not aware of hygienic and sanitary practice.
\end{abstract}

Keywords: Chandigarh area, Food safety, Sanitation, Street food, Vendors

\section{Article Info}

DOI:10.31018/jans.v10i3.1860

Received: April 3, 2017

Revised: June 11, 2018

Accepted: July 30, 2018

\section{How to Cite}

Singh, U. and Thakur, A. (2018). A study on sanitation, hygiene practices and food safety knowledge among food vendors in different sectors of Chandigarh, India. Journal of Applied and Natural Science, 10(3): 931 - 934

\section{INTRODUCTION}

Lifestyle changes and socio economic factors creates very small space for consumers to look at other alternatives one of which would be to prepare one's own meal (Kok and Balkaran, 2014). Mishandling and disregard of hygienic measures on the part of the food vendors may enable pathogenic bacteria to come into contact with food and in some cases survive and multiply in enough numbers to cause illness in the consumers (Chirag et al, 2013).The World Health Assembly (WHA) adopted a resolution in which, the World Health Organization (WHO, 1996) was asked "to give greater emphasis on food safety with the goal of developing suitable, integrated food safety systems for the reduction in health risk along the entire food chain, from main producer to the consumers". By WHO, five keys to safer food are: (i) Keep clean (ii) Separate raw and cooked (iii) Cook thoroughly (iv) Keep food at safe temperatures and (v) Use safe water and raw materials. The word "Sanitation" is derived from the Latin word "Sanitas" which means "health". It is the creation and maintenance of hygienic and healthful conditions while processing, preparing and handling food. Sanitation is a science to provide wholesome food handled in hygienic environment by the food handlers to prevent contamination
(Solanki, 2008). Therefore, the present investigations were conducted to assess the water, sanitation and hygiene (wash) practices and food safety knowledge among food vendors.

\section{MATERIALS AND METHODS}

Study area: The study was conducted in different sectors of Chandigarh. The data were collected by two methods i.e. Questionnaire method and Observation method. Questionnaire was a set of printed written questions about a choice of answers, devised for the purposes of a survey. Observation showed $93 \%$ male vendors and $7 \%$ female vendors; and $42.0 \%$ vendors sold chaat / snacks. Likewise, $58.0 \%$ (42 fixed and 16 mobile) vendors sold full meal. The samples were selected by Purposive Random Sampling method. Hundred Street vendors were selected randomly from different sectors. Fifty vendors were those who served food at stall or mobile vending and other 50 were those who served food at dhaba or fixed vending. The information was gathered either by oral interview/ written questionnaire. A series of questions had been designed to elicit information, which was filled in by all participants in the Questionnaire.

Data collection: After completing the data collection, the questionnaire of vendors was sorted out and arranged in the series. The data were trans- 
Singh, U. and Thakur, A. / J. Appl. \& Nat. Sci. 10 (3): 931 - 934 (2018)

ferred in MS Excel sheet. The collected data got analyzed by SPSS and the results were calculated in mean percentage such as distribution of vendors on basis of gender.

\section{RESULTS AND DISCUSSION}

Distribution of vendors on gender basis: Table 1 showed that distribution of vendors on gender basis. Hundred samples of vendors were selected, it showed that $93.0 \%$ (43 fixed and 50 mobile)

Table 1. Distribution of vendors on gender basis.

\begin{tabular}{lllll}
\hline Vendors & Sex & & Total & $\begin{array}{l}\text { Percent- } \\
\text { age (\%) }\end{array}$ \\
\cline { 2 - 4 } & Males & Females & & $53.0 \%$ \\
\hline Fixed & 43 & 7 & 50 & $93 \%$ \\
Mobile & 50 & 0 & 50 & $7.0 \%$ \\
\hline
\end{tabular}

Table 2. Category of vendors in different sectors.

\begin{tabular}{lcccc}
\hline $\begin{array}{l}\text { Different } \\
\text { Sectors }\end{array}$ & Fixed & Mobile & Total & $\begin{array}{c}\text { Percent- } \\
\text { age (\%) }\end{array}$ \\
\hline Sector-17 & 9 & 10 & 19 & $19.0 \%$ \\
Sector-41 & 20 & 24 & 44 & $44.0 \%$ \\
Sector-19 & 14 & 8 & 22 & $22.0 \%$ \\
Sector-22 & 7 & 5 & 12 & $12.0 \%$ \\
Sector-16 & 0 & 3 & 3 & $3.0 \%$ \\
TOTAL & 50 & 50 & 100 & $100.0 \%$ \\
\hline
\end{tabular}

Table 3. Distribution of vendors on the basis of their meals.

\begin{tabular}{lcccc}
\hline \multirow{2}{*}{ Vendors } & \multicolumn{2}{c}{ Meal } & Tot & $\begin{array}{c}\text { Percentage } \\
\text { (\%) }\end{array}$ \\
\cline { 2 - 3 } & $\begin{array}{c}\text { Chaat/ } \\
\text { Snacks }\end{array}$ & $\begin{array}{c}\text { Full } \\
\text { Meal }\end{array}$ & & $(\%)$ \\
\hline Fixed & 8 & 42 & 50 & $42.0 \%$ \\
Mobile & 34 & 16 & 50 & $58.0 \%$ \\
Total & 42 & 58 & 100 & $100.0 \%$ \\
\hline
\end{tabular}

Table 4. Distributions of vendors on the basis of overall appearance of stall.

\begin{tabular}{lllll}
\hline Appearance & Fixed & Mobile & Total & $\begin{array}{l}\text { Percent- } \\
\text { age (\%) }\end{array}$ \\
\hline $\begin{array}{l}\text { Brand new wed well } \\
\text { used }\end{array}$ & 9 & 9 & 18 & $18.0 \%$ \\
$\begin{array}{l}\text { maintained } \\
\begin{array}{l}\text { Used not well } \\
\text { maintained }\end{array}\end{array}$ & 17 & 21 & 38 & $38.0 \%$ \\
$\begin{array}{l}\text { Poor condition } \\
\text { Total }\end{array}$ & 12 & 14 & 26 & $26.0 \%$ \\
\hline
\end{tabular}

Table 5. Working hours of vendors.

\begin{tabular}{lcccc}
\hline $\begin{array}{l}\text { Hours of } \\
\text { Working }\end{array}$ & Fixed & Mobile & Total & $\begin{array}{c}\text { Percent- } \\
\text { age (\%) }\end{array}$ \\
\hline 2-4 hours & 10 & 13 & 23 & $23.0 \%$ \\
$5-7$ hours & 28 & 20 & 48 & $48.0 \%$ \\
8-10 hours & 12 & 17 & 29 & $29.0 \%$ \\
Total & 50 & 50 & 100 & $100.0 \%$ \\
\hline
\end{tabular}

Table 6. Type of employment.

\begin{tabular}{lllll}
\hline $\begin{array}{l}\text { Own stall or } \\
\text { Employee }\end{array}$ & Fixed & Mobile & Total & $\begin{array}{l}\text { Percent- } \\
\text { age(\%) }\end{array}$ \\
\hline Worker & 4 & 2 & 6 & $6.0 \%$ \\
In charge & 41 & 48 & 89 & $89.0 \%$ \\
employee & 5 & & 5 & $5.0 \%$ \\
Employee & 5 & $\overline{50}$ & 100 & $100.0 \%$ \\
\hline Total & 50 & & & \\
\hline
\end{tabular}

were male vendors and $7.0 \%$ (7 Females) were female vendors, respectively. Rayza et al., 2016) showed that among 43 street food vendors interviewed, $58 \%$ were male, $42 \%$ were aged between 40 and 59 years and $49 \%$ had completed only elementary school in a study during the chain of street food production in Florianopolis, Brazil.

Category of vendors in different sectors: Table 2 category of vendors in different sectors showed the fixed and mobile vendors from different sec-

Table 7. Distributions on the basis of hygienic.

\begin{tabular}{lllll}
\hline Hygiene & Fixed & Mobile & Total & $\begin{array}{l}\text { Percent- } \\
\text { age (\%) }\end{array}$ \\
\hline $\begin{array}{l}\text { Increase Hygiene } \\
\text { Quality }\end{array}$ & 2 & 3 & 5 & $5.1 \%$ \\
Wearing Apron & & & & \\
And Hand Gloves & 4 & 2 & 6 & $4.1 \%$ \\
Maintain Hygiene & 1 & 0 & 1 & $1.0 \%$ \\
Don't Change & 43 & 45 & 88 & $88.0 \%$ \\
Total & 50 & 50 & 100 & $100.0 \%$ \\
\hline
\end{tabular}

Table 8. No. of employees helped in food preparation.

\begin{tabular}{|c|c|c|c|c|}
\hline \multirow[t]{2}{*}{ Vendors } & \multicolumn{2}{|c|}{ Preparation } & \multirow[t]{2}{*}{ Total } & \multirow{2}{*}{$\begin{array}{l}\text { Percentage } \\
(\%)\end{array}$} \\
\hline & Yes & No & & \\
\hline Fixed & 17 & 33 & 50 & $20.0 \%$ \\
\hline Mobile & 3 & 47 & 50 & $80.0 \%$ \\
\hline Total & 20 & 80 & 100 & $100.0 \%$ \\
\hline
\end{tabular}

Table 9. If yes, employees helped in food preparation.

\begin{tabular}{lllll}
\hline \multirow{2}{*}{ Vendors } & \multicolumn{2}{c}{ If yes } & Total & $\begin{array}{l}\text { Percent- } \\
\text { age ( \%) }\end{array}$ \\
\cline { 2 - 3 } & $\begin{array}{l}\text { Family } \\
\text { member }\end{array}$ & Others & & \\
\hline Fixed & 16 & 2 & 18 & $18.0 \%$ \\
Mobile & 2 & 0 & 2 & $2.0 \%$ \\
Total & 18 & 2 & 20 & $20.0 \%$ \\
\hline
\end{tabular}

Table 10. Meals prepared by vendors.

\begin{tabular}{lllll}
\hline Meals & Fixed & Mobile & Total & $\begin{array}{l}\text { Percent- } \\
\text { age (\%) }\end{array}$ \\
\hline One meal & 28 & 45 & 73 & $73.0 \%$ \\
Two meals & 22 & 5 & 27 & $27.0 \%$ \\
Three meals & 0 & 0 & - & $0.0 \%$ \\
Total & 50 & 50 & 100 & $100.0 \%$ \\
\hline
\end{tabular}

Table 11. Distribution on the basis of wash food preparation surface.

\begin{tabular}{lllll}
\hline $\begin{array}{l}\text { Wash food } \\
\text { preparation }\end{array}$ & Fixed & Mobile & Total & Percentage \\
\hline $\begin{array}{l}\text { Everyday } \\
\text { After every }\end{array}$ & 45 & 30 & 75 & $75.00 \%$ \\
meal & 3 & 2 & 5 & $5.00 \%$ \\
Once a week & 0 & 20 & 20 & $20.00 \%$ \\
Total & 50 & 50 & 100 & $100.0 \%$ \\
\hline
\end{tabular}

Table 12. Distribution on the basis of clean surrounding.

\begin{tabular}{|c|c|c|c|c|}
\hline \multirow[b]{2}{*}{ Vendor } & \multicolumn{2}{|c|}{ Clean surrounding } & \multirow[b]{2}{*}{ Total } & \multirow{2}{*}{$\begin{array}{l}\text { Percent- } \\
\text { age (\%) }\end{array}$} \\
\hline & Yes & No & & \\
\hline Fixed & 35 & 15 & 50 & $64.0 \%$ \\
\hline Mobile & 29 & 21 & 50 & $36.0 \%$ \\
\hline Total & 64 & 36 & 100 & $100.0 \%$ \\
\hline
\end{tabular}


Table 13. Distribution on the basis of wash food before cooking.

\begin{tabular}{|c|c|c|c|c|}
\hline \multirow[t]{2}{*}{ Vendor } & \multicolumn{2}{|c|}{ Wash food } & \multirow[t]{2}{*}{ Total } & \multirow{2}{*}{$\begin{array}{l}\text { Percentage } \\
(\%)\end{array}$} \\
\hline & Yes & No & & \\
\hline Fixed & 48 & 2 & 50 & $90.0 \%$ \\
\hline Mobile & 42 & 8 & 50 & $10.0 \%$ \\
\hline Total & 90 & 10 & 100 & $100.0 \%$ \\
\hline
\end{tabular}

Table 14. Distribution on the basis of site where food prepared.

\begin{tabular}{|c|c|c|c|c|}
\hline $\begin{array}{l}\text { Food } \\
\text { prepared }\end{array}$ & Fixed & Mobile & Total & $\begin{array}{l}\text { Percent- } \\
\text { age (\%) }\end{array}$ \\
\hline At home & 36 & 22 & 58 & $58.0 \%$ \\
\hline At site & 14 & 25 & 38 & $38.0 \%$ \\
\hline $\begin{array}{l}\text { Obtain from } \\
\text { other institution }\end{array}$ & 0 & 4 & 4 & $4.0 \%$ \\
\hline Total & 50 & 50 & 100 & $100.0 \%$ \\
\hline
\end{tabular}

tors of Chandigarh. Nineteen percent ( 9 fixed and 10 mobile) vendors were from sectors $17,44.0 \%$ vendors (20 fixed and 24 mobile) from sector 41 , $22.0 \%$ vendors (14 fixed and 8 mobile) taken from sector $19,12.0 \%$ vendors ( 7 fixed and 5 mobile) from sector 22 and $3.0 \%$ (3 mobile) mobile vendors were taken from sector -16 , respectively.

Distribution of vendors on the basis of their meals: Table 3 revealed that $42.0 \%$ (8 fixed and 34 mobile) vendors sold chaat /snacks. Likewise, $58 \%$ (42 fixed and 16 mobile) vendors sold full meal, respectively.

Distribution of vendors on the basis of overall appearance of stall: Table 4 revealed that overall appearance of stall $38.0 \%$ (17 fixed and 21 mobile) vendors used stall but do not well maintain. Likewise $18.0 \%$ (9 fixed and 9 mobile) vendors stall appears like brand new, 18.0\% (12 fixed and 6 mobile) vendors used their stall but well maintained and 26\% (12 fixed and 14 mobile) vendors stall in poor condition

Working hours of vendors: Table 5 showed that $29.0 \%$ (12 fixed and 17 mobile) vendors were working for $8-10$ hours. Likewise $23.0 \%$ (10 fixed and 13 mobile) vendors were working for 2-4 hours and $48 \%$ (28 fixed and 20 mobile) vendors were working for 5- 7 hours. (Joglekar and Bho, 2013) observed that working hours of the vendors that they spent were more than 5 hours in vending.

Type of employment: Table 6 revealed that only $6.0 \%$ (4 fixed and 2 mobile) vendors were work as a worker in stall, $89.0 \%$ (41 fixed and 48 mobile) vendors were in-charge of their stall and only $5.0 \%$ (5 fixed) vendors work as an employee. Jose S. Hilario(2015) noticed that $90 \%$ of street food vendors had concentrated peak hour of their business towards lunchtime and snacks during an evaluation of the hygiene and sanitation practices among street food vendors along Far Eastern University (FEU), Manila at Phillipines.

Table 7 reveals that distribution on the basis of hygiene $88 \%$ don't ever participated in any train- ing programme, $5.1 \%$ increase hygiene quality, $4.1 \%$ wearing apron and hand gloves and only $1 \%$ maintain hygiene.

Distribution of vendors on the basis of preparation process Employees helping in food preparation: Table 8 revealed twenty percent (17 fixed and 3 mobile) vendors employed workers for help in preparation processes, $80 \%$ (33 fixed and 47 mobile) vendors were those who employed no worker for help in preparation. Street food operations involved the work of entire families in the procurement of raw materials, preparation and cooking of meals and their sale. Table 7 showed that $18 \%$ (16 fixed and 2 mobile) vendors take help from their family member and $2.0 \%$ (2 fixed) were those who appoint other than family member. Rayza et al., (2016) showed that $58 \%$ of vendors had 3 family members and more than $30 \%$ had three to five family members in a study during the chain of street food production in Florianopolis, Brazil

Meals prepared by vendors: Table 10 showed that vendors most commonly prepared two meals in a day. Seventy three percent (28 fixed and 45 mobile) vendors prepared one meal per day. Likewise, $27.0 \%$ (22 fixed and 5 mobile) vendors prepared two meals a day.

Table 11suggest that out of the total sample 100, majority of them $(75 \%)$ wash their food preparation surface every day, whereas $20.0 \%$ were wash once a week, only $5.0 \%$ wash their food preparation surface every day.

According to table 12 distribution on the basis of clean surrounding. Out of $100.0 \%$ of the vendors $64 \%$ clean their surroundings and $36.0 \%$ of them are not clean their surroundings. Food Sanitation Unit (2006) found $13 \%$ of vendors have unclean food stall's surface.

Table 13 reveals that $90.0 \%$ of vendors wash their food properly before cooking and $10.0 \%$ out of total did not wash food properly.

Findings show that vendors prepared the foods either at home or at the stalls, which were located by the roadsides. Mostly fixed vendors are prepare food in the stall $(58.0 \%$ ) vendors prepared food from home to site and $38.0 \%$ are prepared food at the site mostly the mobile vendors and only $4.0 \%$ vendors purchase food from other institution .

The present study observed that hygienic practices and food safety were minimal in food street vendors in different sectors of Chandigarh, India. In view of the knowledge of roadside vendors on hygienic practices in food preparation, handling of utensils, place for food preparation and personal hygiene and methods of storing cooked food, it was indicated that vendors had a minimal knowledge of hygienic and sanitary practices. All the vendors, helpers/ $r$ food handlers should undergo a basic training in food hygiene. They must be aware. They also need health education to im- 
prove the knowledge of food vendors on hygiene practices and food safety.

\section{Conclusion}

In a study on water, sanitation and hygiene (wash) practices and food safety knowledge among food vendors in different sectors of Chandigarh area in India, it was concluded that $93.0 \%$ (43 fixed and 50 mobile) were male vendors and $7.0 \%$ (7 Females) were female vendors. Nineteen percent vendors were from sectors $17,44.0 \%$ vendors from sector $41,22.0 \%$ vendors taken from sector $19,12.0 \%$ vendors from sector 22 and $3.0 \%$ mobile vendors were taken from sector $16.42 .0 \%$ (8 fixed and 34 mobile) vendors sold chaat /snacks. Likewise, $58.0 \%$ (42 fixed and 16 mobile) vendors sold full meal. Overall appearance of stall $38.0 \%$ (17 fixed and 21 mobile) vendors used stall, but do not well maintain. Likewise, 18.0\% (9 fixed and 9 mobile) vendors stall appears like brand new, $18.0 \%$ (12 fixed and 6 mobile) vendors used their stall, but well maintained and $26 \%$ (12 fixed and 14 mobile) vendors stall in poor condition. $6.0 \%$ vendors worked as workers in stall, $89.0 \%$ vendors were in-charge of their stall and only $5.0 \%$ (5 fixed) vendors worked as an employee. Twenty percent (17 fixed and 3 mobile) vendors employed as workers helped in preparation process, $80 \%$ (33 fixed and 47 mobile) vendors were those who employed no worker helped in preparation process. This research recommends that every fixed and mobile vendor food handler should undergo a basic safe street food training programmes to have knowledge of hygiene practices.

\section{REFERENCES}

1. Rayza Dal MolinCortese, Marcela BoroVeiros, CharlesFeldman, Suzi BarlettoCavalli (2016). Food safety and hygiene practices of vendors during the chain of street food production in Florianopolis, Brazil, Food Control,62, 178-186.

2. G Chirag, Lakshmi BK and Kumar A (2013). Study of Hygienic practices of street food vendors in Allahabad city, India and Determination of Critical control points for safe street food. The Allahabad Farmer, LXVIII (2), 1-10

3. Solanki (2008). Nutritional and Hygienic Assessment of Food sold by Small Vendors in Rajkot City, Ph.D Thesis, Saurashtra University Rajkot, India.

4. Joglekar.A, Bho .S. (2013).A study on personal hygiene of street food vendors of Raipur

5. City, Asian Journal of Home Science, 8(2):586-589.

6. Jose S. Hilario (2015). An Evaluation of the Hygiene and Sanitation Practices Among Street Food Vendors Along Far Eastern University (FEU), International Journal of Advanced Research,3(2):604-615.

7. Kok R and Balkaran R (2014). Street Food Vending and Hygiene Practices and Implications for Consumers Durban University of Technology South Africa. Journal of Economics and Behavioral Studies, 6(3), 188-193.

8. WHO (1996). Essential Safety Requirements for Street Vended 60 Foods. Food Safety Unit, Division of Food and Nutrition (World Health Organization) Geneva.(ONLINE).Available:http://www.who.int/food safety/publications/fs_managementen/ street vend. pdf, retrieved on $13^{\text {th }}$ may, 2015. 